\title{
Retrospective Analysis of Canine \\ Vector-borne Diseases (CVBD) in Germany \\ with Emphasis on the Endemicity and \\ Risk Factors of Leishmaniosis
}

Majda Globokar Vrhovec ${ }^{1} \bowtie$, Nikola Pantchev ${ }^{1} \bowtie$, Klaus Failing², Christian Bauer $^{3}$,

Nora Travers-Martin', Horst Zahner ${ }^{3}$

1 IDEXX Laboratories, 71636 Ludwigsburg, Germany

${ }^{2}$ Unit for Biomathematics and Data Processing, Justus-Liebig-University, 35392 Giessen, Germany

${ }^{3}$ Institute of Parasitology, Justus Liebig University Giessen, 35392 Giessen, Germany

Corresponding authors:

Majda Globokar Vrhovec

$\triangle$ E-mail: majda-globokar@idexx.com

Nikola Pantchev

$\triangle$ E-mail: nikola-pantchev@idexx.com

\section{Abstract}

A cross-sectional study was designed to provide data on the detection of canine vector-borne diseases (CVBDs) with special emphasis on leishmaniosis in Germany. For this purpose, results of blood or serum samples sent by local veterinarians to a veterinary diagnostic laboratory were retrospectively analysed. Samples were examined for Leishmania spp., Babesia spp., Ehrlichia canis, Dirofilaria immitis and Anaplasma phagocytophilum during the years 2004-2006 and 2014-2016 (Leishmania only). Erythrocyte stages of large Babesia spp. or Babesia DNA were found in 1.7\% of 9,966 blood smears and $3.3 \%$ of 15,555 samples examined by PCR, respectively. Large Babesia merozoites were found more frequently in Giemsastained smears from dogs born in Germany when compared to blood samples of dogs originating from south or south-east European countries. A total of 15 blood samples of German dogs which have never been abroad were positive for Babesia DNA. Antibodies titres $(>=80)$ against Babesia canis were detected by IFAT in $11.5 \%$ of 2,653 serum samples. Out of 570 samples $3.2 \%$ were positive for $E$. canis using PCR. Antibodies against E. canis and A. phagocytophilum (both at titres $>=50$ ) were detected by indirect IFAT in $15.1 \%$ and $41.9 \%$ of 18,652 and 794 serum samples, respectively. Using Knott's test $4.5 \%$ of 440 blood samples were positive for microfilariae, and Dirofilaria immitis antigen was found by ELISA in $1.4 \%$ of 
9,381 serum samples. Leishmania spp. DNA was detected in $11 \%$ of 301 whole blood or tissue samples examined by PCR. Antibodies against Leishmania were found in $23.5 \%$ (23,665 samples) and $22.7 \%$ (54,103 samples) of blood samples by IFAT (titres $>=50$ ) and ELISA ( $>=7$ test units), respectively (2004-2006 versus 2014-2016). Antibodies against Leishmania (IFAT) were detected in $80.6 \%$ (399/495) of dogs imported from endemic areas, in $57.6 \%(34 / 59)$ of German dogs travelling outside Germany and in $4(n=8)$ German dogs without any history of travelling. Potential endemicity of leishmaniosis in Southern Germany was prospectively evaluated. For some of these infectious agents, sex or age of dogs and season were identified as risk factors.

\section{Introduction}

Dogs are in close contact with humans and other animals and are exposed to a wide range of pathogens. They can act as a reservoir of pathogens of zoonotic and veterinary importance (Otranto et al. 2009b). Canine vector-borne diseases (CVBDs) are caused by parasites, bacteria or viruses transmitted by the bite of hematophagous arthropods (mainly ticks and mosquitoes). The occurrence of some vector-borne diseases of dogs and cats is increasing in Europe, i.e., canine leishmaniosis and filariosis (Otranto et al. 2009a, Pantchev et al. 2011, Wolf et al. 2014) or babesiosis (Pantchev et al. 2015a). CVBDs show an impact on animal and human health and a spread to non-endemic areas (Hirsch and Pantchev 2008). Some changes, such as traveling with pets, changes in human habitats, social and hobby activities, but also climate changes have a direct impact on arthropod vectors (abundance, geographical distribution and vectorial capacity) as well as development of vector-borne diseases within the vectors (Gothe 1991, Gothe et al. 1997). Arthropod-borne diseases are gaining importance in Germany as emerging endemic parasites and have been increasingly diagnosed in veterinary practices. This is reflected by a high number of dogs examined in this survey. The objective of this study was to characterize the occurrence of vectorborne pathogens in native German dogs (without history of travelling), in German dogs travelling to potentially endemic areas and dogs from endemic areas imported to Germany with special emphasis on endemicity and risk factors for leishmaniosis.

\section{Material and methods}

The retrospective study involved results of examinations of 30,970 and 54,103 canine blood or serum samples, routinely submitted by German veterinarians to a veterinary diagnostic laboratory (IDEXX Laboratories, Ludwigsburg) from 2004 to 2006 and from 2014 to 2016, respectively. These samples had been tested for Babesia spp., E. canis, A. phagocytophilum, and D. immitis (in 20042006 only) and Leishmania spp. (in both examination periods). The samples had not been randomly collected because a large proportion of them had been submitted either as a part of a "travel disease profile" or with clinical suspicion. Information on the age, gender, origin or travel history of the dogs were available for a part of the samples. Additionally, in 2004-2006, telephone interviews with the respective veterinarians were performed for dogs being Babesia-positive using blood smears or PCR, being Leishmania-positive using PCR or having Leishmania antibodies (titer $>=200$ ) as well as being positive for $D$. immitis antigen to receive data on the place of birth and residence as well as travelling of these dogs. Furthermore, $45 \mathrm{dogs}$ were prospectively tested by Leishmania PCR of conjunctival swabs (left and right eyes were sampled), presented 2007 at two veterinary clinics in Southern Germany (Urbach and Schwanstetten) for various reasons.

Giemsa-stained blood smears $(\mathrm{n}=9,966)$ were performed as usual and examined for Babesia spp. stages. 
Whole blood samples $(n=440)$ were examined for microfilariae using a modified Knott's test according to Pantchev et al. (2009a, 2011). Serum samples $(n=9,381)$ were tested for circulated $D$. immitis antigen by a commercial rapid assay test system (IDEXX SNAP ${ }^{\circledR}$ canine heartworm ${ }^{\circledR}$ ) following the manufacturer's instructions (see also Pantchev et al. (2009b)).

For molecular diagnosis of Babesia spp. (15,155 samples) and E. canis (570 samples), DNA was extracted from whole blood samples according to Dyachenko et al. (2012), and a conventional PCR was performed according to Carret et al. (1999), targeting the SSU rDNA gene (Babesia spp.) and to McBride et al. (1996), targeting the $16 \mathrm{~S}$ ribosomal RNA gene (E. canis). For molecular diagnosis of Leishmania spp., DNA was extracted from different samples (lymph nodes, skin, spleen, liver, nasal discharge, join puncture, urine, bone marrow or whole blood; $n=301$ ), and a conventional PCR targeting the SSU rDNA was implemented according to van Eys et al. (1992). In presumably autochthonous Leishmania-positive samples $(\mathrm{n}=2)$ a second conventional PCR targeting the kinetoplast DNA (kDNA) minicircles was performed as described by Le Fichoux et al. (1999) to confirm the results. The latter PCR was also implemented to prospectively test dogs $(n=45)$ by means of ocular swabs. In the present study no determination on species level for Babesia and Leishmania was performed.

The presence of IgG antibodies against Babesia spp. had been tested in 2,653 serum samples by a commercial indirect IFAT (MegaScreen FLUOBABESIA, Diagnostik MegaCor GmbH, Hörbranz, Austria) following the manufacturer's instructions. The test cutoff was set at dilutions of $>=1: 80$. Titre of 80 was considered low (borderline) and titres $>=160$ positive.

For IgG antibodies against $E$. canis, 18,652 samples had been examined by a commercial indirect IFAT (MegaScreen FLUOEHRLICHIA canis, Diagnostik MegaCor GmbH, Hörbranz, Austria).
The test cutoff was set at dilutions of $>=1: 50$. Titres of 50 and 100 were considered low (borderline) and titres $>=200$ positive. As a modification with regard to kit contents, another FITC-conjugated secondary antibody was used at a dilution of 1:1000 (Fluorescein-labeled affinity purified antibody to dog IgG produced in goat from Kirkegaard \& Perry Laboratories), with Evans Blue (2.5 ml, Bio-Rad) as counter stain and Biognost ${ }^{\circledR}$ mounting medium (Bios) to cover the wells prior to microscopy.

The presence of IgG antibodies against A. phagocytophilum had been tested in 794 samples by a commercial indirect IFAT (MegaScreen FLUOANAPLASMA phagocytophilum, Diagnostik MegaCor GmbH, Hörbranz, Austria) according to Pantchev et al. (2015b). The test cutoff was set at dilutions of $>=1: 50$. Titres of 50 and 100 were considered low (borderline) and titres $>=200$ positive.

In 2004-2006, 23,665 serum samples had been tested for the presence of IgG antibodies against Leishmania spp. using a commercial indirect IFAT (Mega Screen ${ }^{\circledR}$ FLUOLEISH, Diagnostik MegaCor GmbH, Hörbranz, Austria) according to Wolf et al. (2014). The test cutoff was set at dilutions of $>=1: 50$. Titres of 50 and 100 were considered low (borderline) and titres $>=200$ positive. In 2014-2016, 54,103 samples were examined using an ELISA (Leishmania-ELISA-Dog, Afosa, Luckenwalde, Germany) according to the manufacturer's instructions (see also Wolf et al. 2014). This ELISA converts the colorimetric data into test units classed in the following test ranges: negative $(<7)$, borderline (7-12), and positive ( $>12)$.

The statistical analysis was performed using the BMDP/Dynamic, Release 7.0 (Dixon 1993). The observed prevalence and $95 \%$ confidence intervals (CI) were calculated for each pathogen. Results were analysed using chi-square test. To identify risk factors for parasite infestation, a multivariable logistic regression approach was used. Differences with $P$ values $<0.05$ were considered as significant. Statistical analysis of serological examinations included low (borderline) and positive titres. 


\section{Results}

\section{Leishmania}

Leishmania spp. DNA was detected in $11 \%$ (CI: 7.7-15.1\%; $\mathrm{n}=33$ ) of 301 samples examined by PCR. Regarding the sample type, Leishmania DNA was detected in 16 out of 245 blood samples (6.5\%; CI: $3.8-10.4 \%)$ and 10 out of 15 (66.7\%; CI: $38.4-88.2 \%)$ skin scrapings. All four joint punctures, both blood smears as well as one of two tested bone marrow samples were also tested positive. The origins of positively tested dogs in the retrospective analysis were as follows: 13 dogs were imported (nine originated from Spain/Portugal, one each from Italy and Greece and two from other countries), two PCR positive dogs had a travel history to Spain/Portugal. Risk factors were not identified by multivariate logistic regression. All 90 conjunctival swabs (from 45 dogs), examined during the prospective study at two sites in Southern Germany, revealed negative results.

In 2004-2006, antibodies against Leishmania were found in $23.5 \%$ (CI: $23.0-24.1 \%$; $=5,572$ ) of the samples using IFAT. Positive titres were detected in $10.5 \%$ (CI: 10.1-10.9\%; $\mathrm{n}=2,477$ ) of the samples; additional $13.1 \%$ (CI: 12.7-13.5\%; $\mathrm{n}=3,095$ ) of the sera showed low (borderline) results (Table 1). On multivariate logistic regression, the prevalence of Leishmania antibodies was higher in older ( $>12$ months) than in younger ( $<12$ months) dogs $(\mathrm{p}<0.001)$. Male dogs were significantly more often seropositive than female dogs $(p<0.05)$. From 67 dogs born in Germany, 59 travelled outside the country (34 dogs were seropositive and 25 were seronegative for Leishmania) and 8 dogs have never left Germany (Table 2). One of those eight dogs had a low (borderline) titre, and another three showed positive titres of $200(n=2)$ and 400 $(n=1)$. All three dogs originated from the southern part of Germany, two from Baden Württemberg (Urbach and Welzheim) and one from Franconia (Schwanstetten near Nürnberg). Furthermore, in two of those dogs with positive titres and no travel history (from Urbach and Schwanstetten), Leishmania DNA was detected.

In 2014-2016, antibodies against $L$. infantum were detected by ELISA in $22.7 \%$ (CI: 22.4-23.1\%; $\mathrm{n}=12,320$ ) of the samples. Positive results ( $>12$ test units) were detected in $18.6 \%$ (CI: 18.3-18.9\%; $\mathrm{n}=10,056)$ of the sera, while another $4.2 \%$ (CI: $4.0-4.4 \% ; n=2,264)$ of the samples showed borderline results. The proportion of Leishmania seropositive samples was significantly higher $(\mathrm{p}<0.001)$ in 2014-2016 (18.6\%) than in 2004-2006 (10.5\%) using ELISA and IFAT, respectively. However, both examination periods did not differ significantly

Table 1 IFAT results for antibodies against $L$. infantum in 23,665 canine serum samples from 2004-2006

\begin{tabular}{|c|c|c|c|}
\hline & Titre & $\%$ & $95-\mathrm{Cl}^{1}$ \\
\hline \multirow{2}{*}{ negative } & $<50$ & 76.5 & $75.9-77.0$ \\
\hline \multirow{3}{*}{ low (borderline) } & 50 & 9.6 & $9.2-10.0$ \\
\cline { 2 - 4 } & 100 & 3.5 & $3.3-3.7$ \\
\hline \multirow{3}{*}{ positive } & 200 & 2.3 & $2.1-2.5$ \\
\cline { 2 - 4 } & 400 & 0.9 & $0.7-1.0$ \\
\cline { 2 - 4 } & 800 & 2.2 & $2.0-2.4$ \\
\cline { 2 - 4 } & 1,600 & 0.5 & $0.5-0.7$ \\
\cline { 2 - 4 } & 3,200 & 3.3 & $3.1-3.5$ \\
\hline
\end{tabular}

$195 \%$ confidence interval 
Table 2 Relation between origin/travelling of dogs and detection of $L$. infantum antibodies $(n=562)$

\begin{tabular}{|c|c|c|c|}
\hline group & $\begin{array}{r}\text { travelling }(A) \text { or } \\
\text { origin (B) }\end{array}$ & $\mathbf{n}$ & $\%$ seropositive \\
\hline $\begin{array}{r}\text { A) dogs from Germany (totally) } \\
\text { no travelling } \\
\text { travelling (totally) }\end{array}$ & $\begin{array}{r}\text { Spain/Portugal } \\
\text { Italy } \\
\text { Greece }{ }^{1} \\
\text { Hungary } \\
\text { Southern Europe } \\
\text { other countries } \\
\text { unknown }\end{array}$ & $\begin{array}{r}67 \\
8 \\
59 \\
15 \\
4 \\
10 \\
7 \\
4 \\
13 \\
6\end{array}$ & $\begin{array}{r}56.7 \\
50.0 \\
57.6 \\
73.3 \\
100.0 \\
70.0 \\
0 \\
50.0 \\
46.1 \\
66.6\end{array}$ \\
\hline $\begin{array}{r}\text { B) dogs not from Germany } \\
\text { (totally) }\end{array}$ & $\begin{array}{r}\text { Spain/Portugal } \\
\text { Italy } \\
\text { Greece }{ }^{1} \\
\text { Turkey } \\
\text { Hungary } \\
\text { Southern Europe } \\
\text { other countries } \\
\text { unknown }\end{array}$ & $\begin{array}{r}495 \\
240 \\
52 \\
75 \\
4 \\
12 \\
30 \\
23 \\
59\end{array}$ & $\begin{array}{l}80.6 \\
\\
84.6 \\
92.3 \\
81.3 \\
75.0 \\
33.3 \\
70.0 \\
47.8 \\
81.3\end{array}$ \\
\hline
\end{tabular}

1 incl. former Yugoslavia

Table 3 Relation between origin/travelling of dogs and detection of Babesia spp. (by Giemsa-stained blood smear, $\mathrm{n}=165$ and $P C R, \mathrm{n}=332$ )

\begin{tabular}{|c|c|c|c|c|c|}
\hline & & \multicolumn{2}{|c|}{$\begin{array}{l}\text { Giemsa-stained } \\
\text { blood smear }\end{array}$} & \multicolumn{2}{|r|}{ PCR } \\
\hline group & $\begin{array}{r}\text { travelling }(A) \text { or } \\
\text { origin (B) }\end{array}$ & $n$ & $\begin{array}{r}\% \text { sample } \\
\text { positive }\end{array}$ & $n$ & $\begin{array}{r}\% \text { sample } \\
\text { positive }\end{array}$ \\
\hline $\begin{array}{r}\text { A) dogs from Germany (totally) } \\
\text { no travelling } \\
\text { travelling (totally) }\end{array}$ & $\begin{array}{r}\text { Spain/Portugal } \\
\text { Italy } \\
\text { Greece }{ }^{1} \\
\text { Hungary } \\
\text { Southern Europe } \\
\text { other countries } \\
\text { unknown }\end{array}$ & $\begin{array}{r}40 \\
8 \\
32 \\
8 \\
1 \\
4 \\
6 \\
2 \\
10 \\
1\end{array}$ & $\begin{array}{r}52.2 \\
87.5 \\
43.8 \\
12.5 \\
0 \\
50.0 \\
83.3 \\
50.0 \\
50.0 \\
0\end{array}$ & $\begin{array}{r}75 \\
15 \\
60 \\
13 \\
2 \\
6 \\
12 \\
3 \\
17 \\
7\end{array}$ & $\begin{array}{r}76.0 \\
100.0 \\
70.0 \\
46.1 \\
50.0 \\
50.0 \\
100.0 \\
66.7 \\
88.2 \\
42.8\end{array}$ \\
\hline $\begin{array}{r}\text { dogs not from Germany } \\
\text { (totally) }\end{array}$ & $\begin{array}{r}\text { Spain/Portugal } \\
\text { Italy } \\
\text { Greece }{ }^{1} \\
\text { Turkey } \\
\text { Hungary } \\
\text { Southern Europe } \\
\text { other countries } \\
\text { unknown }\end{array}$ & $\begin{array}{r}125 \\
57 \\
8 \\
19 \\
0 \\
4 \\
9 \\
13 \\
15\end{array}$ & $\begin{array}{r}9.6 \\
\\
1.7 \\
12.5 \\
0 \\
0 \\
25.0 \\
0 \\
53.8 \\
13.3\end{array}$ & $\begin{array}{r}257 \\
114 \\
22 \\
35 \\
1 \\
9 \\
19 \\
21 \\
36\end{array}$ & $\begin{array}{r}42.4 \\
\\
38.6 \\
27.3 \\
37.1 \\
0 \\
77.8 \\
52.6 \\
81.0 \\
33.3\end{array}$ \\
\hline
\end{tabular}

1 incl. former Yugoslavia 
when borderline results were considered as positive $(22.7 \%$ vs. $23.5 \%)$.

\section{Babesia}

Erythrocyte stages of large Babesia spp. were detected in $1.7 \%(\mathrm{CI}=1.5-2.0 \% ; \mathrm{n}=170)$ of the Giemsa-stained blood smears. Considering the multivariable logistic regression, male dogs were more often infected with Babesia spp. than bitches ( $<<0.05)$, and positive blood smears were more often found in spring and autumn than in winter $(\mathrm{p}<0.001)$. Additionally, Babesia stages were more frequently detected in samples of dogs born in Germany than in those originating from other countries. Babesia DNA was detected in $3.3 \%$ $(\mathrm{CI}=3.0-3.6 \% ; \mathrm{n}=502)$ of the samples examined by PCR. The proportion of DNA-positive results was significantly higher $(\mathrm{p}<0.05)$ for younger $(<1$ year $)$ than for older dogs as well as for male dogs than for bitches. Babesia DNA was more often detected from samples collected in spring and autumn than in winter $(\mathrm{p}<0.001)$. A significant association between detection of Babesia DNA and dog's origin $(p<0.001)$ or travelling $(p<0.01)$ could be shown (Table 3).

The results of the Giemsa-stained blood smears moderately correlated with those of the PCR (kappa value: 0.54 ). The relative sensitivity and relative specificity of the blood smear was $38 \%$ (CI: 32.4-44.2\%) and 99\% (CI: 99.8-99.9\%), respectively, employing the PCR as the gold standard.

Antibodies against B. canis were detected in $11.5 \%$ (CI: $10.3-12.8 \% ; \mathrm{n}=306$ ) of the serum samples. $3.8 \%$ (CI: $3.1-4.6 \% ; n=100$ ) of dogs showed low (borderline) titres, while positive titres were found in $7.8 \%$ of the samples (CI: $6.8-8.8 \%$; $\mathrm{n}=206$ ). Male dogs were significantly more often seropositive than bitches $(p<0.01)$. No other risk factors could be identified using the multivariate logistic regression.

\section{Ehrlichia canis}

E. canis DNA was isolated from $3.2 \%$ (CI: $1.9-4.9 \%$; $\mathrm{n}=18$ ) blood samples using PCR. Risk factors were not identified by a multivariable analysis.

Antibodies against E. canis were found in $15.1 \%$ (CI: $14.6-15.65 \%$; $\mathrm{n}=2,816)$ of the serum samples. $8.5 \%$ (CI: $9.1-8.9 \% ; n=1,585$ ) of canine sera showed positive titres, while low (borderline) titres were found in $6.6 \%$ of the samples (CI: $6.2-7.0 \%$; $\mathrm{n}=1,231$ ). Female dogs had 1.2-fold higher chance to be $E$. canis seropositive than male dogs $(\mathrm{p}<0.05)$; the age of dogs was not found as a risk factor. $E$. canis antibodies were more often detected from samples collected in autumn (18.8\%) compared to winter $(15.5 \%)$, spring $(10.8 \%)$ and summer $(14.6 \%)(\mathrm{p}<0.001)$.

\section{Anaplasma phagocytophilum}

Antibodies against A. phagocytophilum were detected in $41.9 \%$ (CI: $37.5-44.4 \%$; $=325$ ) of the serum samples. Positive titres were detected in $36.2 \%$ (CI: $32.8-39.6 \%$; $\mathrm{n}=287$ ) of the sera, while $5.7 \%$ (CI: $4.2-7.5 \% ; \mathrm{n}=45$ ) showed low (borderline) titres. Antibodies were more likely to be detected in dogs older than 12 months than in dogs younger than 12 months $(\mathrm{p}<0.001)$.

\section{Filariae}

Microfilariae and D. immitis antigens were found in $4.5 \%(\mathrm{CI}: 2.8-6.9 \% ; \mathrm{n}=440)$ and $1.4 \%(\mathrm{CI}$ : $1.2-1.7 \% ; n=9,381$ ) of samples, respectively. Dogs aged $>12$ months were found to be more often seropositive for heartworm antigen than younger dogs $(p<0.01)$. All 10 antigen positive dogs with known origin dogs were imported to Germany. No significant association was found between $D$. immitis and the origin of the dogs (data not shown).

\section{Co-infections}

Co-infections of vector-borne diseases were also observed (Table 4). Antibodies against Leishmania and Ehrlichia were detected most frequently (in 617 of 15,955 samples). 
Table 4 Number of dogs with mixed infections

\begin{tabular}{|l|l|l|l|}
\hline & $\begin{array}{l}\text { Leishmania IFAT } \\
\text { positive } \\
\text { (n examined) }\end{array}$ & $\begin{array}{l}\text { Babesia IFAT } \\
\text { positive } \\
\text { (n examined) }\end{array}$ & $\begin{array}{l}\text { Ehrlichia IFAT } \\
\text { positive } \\
\text { (n examined) }\end{array}$ \\
\hline Babesia Giemsa-stained blood smear & $8(6,915)^{*}$ & $3(156)^{n s}$ & $10(6,975)^{n s}$ \\
\hline Babesia PCR & $88(14,194)^{n s}$ & $16(197)^{* *}$ & $64(14,229)^{n s}$ \\
\hline Microfilariae Knott's test & $3(108)^{n s}$ & $1(16)^{n s}$ & - \\
\hline Ehrlichia PCR & $4(104)^{n s}$ & $1(23)^{n s}$ & $8(133)^{n s}$ \\
\hline Babesia IFAT & $50(777)^{* *}$ & - & $42(1,252)^{* *}$ \\
\hline Ehrlichia IFAT & $617(15,955)^{* *}$ & - & - \\
\hline Anaplasma IFAT & $5(96)^{*}$ & $6(157)^{n s}$ & $21(293)^{n s}$ \\
\hline
\end{tabular}

* significant $(p<0.05) \quad$ ** high significant $(p<0.001) \quad{ }^{n s}$ not significant $(p>0.05)$

\section{Discussion}

This retrospective study evaluated a large number of canine samples, routinely submitted by German veterinarians to a diagnostic veterinary laboratory. Occurrence and risk factors for Leishmania, Babesia, E. canis, D. immitis and A. phagocytophilum were shown. Additionally, possible autochthones cases of leishmaniosis were assumed and potential endemicity of leishmaniosis was prospectively evaluated. Finally, seroprevalence of antibodies to Leishmania spp. were compared for the periods of 2004-2006 and 2014-2016.

\section{Leishmania}

Leishmania spp. DNA was detected in $11 \%(\mathrm{n}=33)$ of 301 samples examined by PCR targeting the SSU rDNA. For 15 positive samples, information regarding the origin of dogs could be acquired. They were all either imported or traveled to endemic countries (mainly Spain or Portugal). Using PCR technique, sensitivity depends on the parasite numbers within the biological material obtained (Hernandez et al. 2015) and the copy numbers of target gene. Parasite numbers within a certain material could be further influenced by time point of infection (Hernandez et al. 2015) or treatment (Manna et al. 2015). Sensitivity of $87 \%$ for blood samples and $100 \%$ for bone marrow was shown by Steuber et al. (1998). Using other samples like spleen or lymph node aspirates a sensitivity of $86 \%$ was demonstrated by Maia et al. (2009). StraussAyali et al. (2004) reported about slightly higher sensitivity (92\%) for conjunctival swabs (sampled from both eyes). In contrast, another study found lower amounts of parasites in conjunctival swabs on days 120 and 360 p.i. compared to vulvar or oral swabs as well as to blood or bone marrow samples (Hernandez et al. 2015). This could be due to the different PCR protocols (nested/conventional/ real-time PCR; gene target) of respective studies, or because swabs do not contain a uniform cell number, depending on the technique of sampling. The most sensitive PCR assay is the method using kinetoplast DNA (kDNA), detecting the copy number of the target regions between 50 - and 250 -fold higher than splice leader mini-exon (SLME) and the SSU rRNA (ITS1) (Bensoussan et al. 2006). In the present study, Leishmania DNA was found in blood samples, skin scrapings, joint punctures and in bone marrow. All four joint samples were positive, which is particularly interesting. Agut et al. (2003) and Soubasia et al. (2013) reported about leishmanial arthritis in dogs. Leishmaniosis associated with a joint disease shows an erosive or none-erosive mono- or polyarthritis with 
lymphoplastic to granulomatous inflammation. Leishmania amastigotes damage synovial membranes and cause neutrophilic inflammation. Additionally, immune complexes accumulate and lead to orthopaedic disorders (Saridomichelakis 2009). Typical clinical sign is lameness, but neuralgia, foot pad ulceration, polymyositis and osteomyelitis can also occur. This leads to severe destructive osteolytic and osteoproliferative injuries of long bones.

Positive Leishmania antibody titres observed in 2004-2006 (10.4\%; IFAT) were significantly lower than the proportion of positive results in 20142016 (18.6\%; ELISA). Nevertheless, if borderline results are allocated as positive, there was no statistically significant difference of Leishmania seroprevalence from 2004-2006 (23.5\%) to 2014-2016 (22.8\%). IFAT and ELISA technique, based on whole-cell $L$. infantum MON1 antigen, are the most used methods for detecting Leishmania antibodies in dogs (Wolf et al. 2014). Both tests have a high sensitivity and specificity and provide quantitative results (Solano-Gallego et al. 2014), but, they are not able to discriminate antileishmanial antibodies in Leishmania-infected or vaccinated dogs (Paltrinieri et al. 2016). Overall the two assays (IFAT and ELISA) utilized in the present study showed high accordance regarding the percentage of identical results $(83.7 \%$; $r s=0.90, p<0.0001)$ (Wolf et al. 2014). Within the period 2004-2006 antibodies were found in $92.3 \%$ dogs originating from Italy, $84.6 \%$ from Spain/Portugal, $81.3 \%$ from Greece/ former Yugoslavia and $33.3 \%$ from Hungary. Moreover, $73.3 \%$ of German dogs with travel history in Spain/Portugal, 70\% in Greece/former Yugoslavia and $100 \%$ in Italy, had also contact to Leishmania (Table 2). The detection of Leishmania antibodies in the present study confirmed serological data for dogs tested positive in the Netherlands, imported from Southern Europe (Teske et al. 2002). Meanwhile many imported dogs with CVBD, introduced to Central Europe, originate rather from eastern than from the southern European countries (Willi et al. 2015). Nevertheless, detection of antibodies between 2014-2016 did not significantly decrease in contrast to the previous time period. This might either reflect a long seropositivity state or increasing occurrence of leishmanial infections also in eastern European countries (e.g. Romania, Dumitrache et al. 2016).

A significant association was found between risk factors like gender and age, and detection of Leishmania antibodies. Leishmania antibodies were detected more frequently in male than in female dogs. These findings corresponded with results of Zaffaroni et al. (1999), Cringoli et al., (2002), Keck and Dereure (2003), Mettler et al. (2005), Zivicnjak et al. (2005) and Solano-Gallego et al. (2006). This can be explained by an increased outdoor activity in males. According to our findings, the risk for older dogs was higher than for younger. Cringoli et al. (2002), Mettler et al. (2005), Miro et al. (2007), Alonso et al. (2010), Cortes et al. (2012) and Carvalho et al. (2015) observed more frequently $L$. infantum antibodies in dogs with increased age. Old dogs may be more affected due to longer exposure to vectors in many transmission seasons. In contrast, Leontides et al. (2002) and Cardoso et al. (2004) did not consider age as a risk factor for leishmaniosis.

Four dogs with antibodies to Leishmania have never left Germany regarding the statement of their owners. Three of those dogs with titres of 200 or higher originated from southern part of Germany, two from Baden Württemberg and one from Franconia; in two dogs, leishmaniosis was additionally confirmed by two different PCR protocols. Autochthonous infections due to sand fly bites are unlikely as competent vectors for human and canine leishmaniasis as e.g. Phebotomus perniciosus has not been detected in Southern Germany since first finding (Beran 2010, Haeberlein et al. 2013). So far, Naucke and Schmitt (2004) observed P. perniciosus only once in Southern Germany. Another sand fly species, Phlebotomus mascittii, was reported recently in Germany (German state of Hesse) by Melaun et al. (2014). In Eastern Austria a stable population for $P$. mascitii seems to 
exist (Obwaller et al. 2014). Despite isolated findings of $P$. mascittii in Germany, the vector competence of this sand fly species for Leishmania has not been verified yet. A recent study from Austria found L. infantum DNA in one P. mascittii, but did not provide evidence of metacyclic promastigotes or prove of transmission through experimental infections (Obwaller et al. 2016). Prospective examinations were conducted in Urbach and Schwanstetten (location of the two DNA positive dogs presumably infected in Germany) by analyzing conjunctival swabs from 16 and 29 dogs, respectively, presented in the same clinics for various reasons. All swabs were negative for Leishmania DNA pointing toward either a non-autochthonous infection (not reported or unknown to current dog owners) or a non-vector transmission in these two dogs. Possible mechanisms include breeding, vertical transmission, blood transfusion, and possible biting (e.g. Karkamo et al. 2014). Vectors, such as sand flies, could also be introduced accidentally to non-endemic areas via travel equipment.

\section{Babesia}

The prevalence of babesiosis depends on tick population and occurrence of Babesia in ticks. Babesiosis in Germany caused by $B$. canis is no longer a "travel disease". The pathogen occurs in some foci in different regions. Varies factors (global warming, ecological habitat changes, increased host and vector population, and increased mobility of owners with their dogs) probably caused spreading of ticks and this piroplasm (Zahler et al. 2000, Barutzki et al. 2007). In the present study, data from three different diagnostic procedures for Babesia were evaluated. In dogs living in Germany, antibodies (IFAT) were detected in $11.5 \%$, parasitic stages (Giemsa-stained blood smears) in $1.7 \%$ and DNA (PCR) in $3.3 \%$ of submitted samples. Detection of large Babesia merozoites in Giemsa-stained blood and Babesia DNA in blood samples were observed significantly often in native dogs from Germany (without travel history) than in imported dogs (Table 3). These data agree with recent serological data (B. canis ELISA) obtained for Germany (Pantchev et al. 2015a). A possible explanation is that a larger proportion of the animals with a history of travel were tested preventively irrespective of symptoms, whereas the animals that had stayed within Germany were tested on the basis of clinical suspicion. Dogs travelling with their owners to Hungary were frequently more often infected with Babesia than dogs staying in other countries. Regarding results of the present study, it can be concluded that the highest risk for canine babesiosis exists in Germany and in Hungary. Furthermore, Babesia (using Giemsastained blood smears and PCR) were found more frequently in male than in female dogs. Moreover, higher occurrence of Babesia DNA was detected in younger than in older dogs. Puppies and young dogs seem to be more susceptible for this protozoan than adult dogs; the outcome can be lethal if not diagnosed and treated properly (Farwell et al. 1982). Our results confirmed the surveys from Gothe et al. (1989), Porchet et al. (2007) and Zygner et al. (2009) regarding the seasonal distribution of Babesia with a peak in spring and autumn. This is associated with a seasonal activity of vector, Dermacentor reticulatus in March/April and October/ November. As the present study demonstrated, a single microscopic blood smear test, compared with PCR as the established gold standard, had a relative sensitivity of only $38 \%$ and a relative specificity of over $99 \%$. Another major advantage of the PCR technique is that, following a positive Babesia result, differentiation of species can subsequently be performed by either species-specific real-time PCRs or SSU rDNA amplification with subsequent sequencing (Pantchev et al. 2015a).

\section{Filariae}

Microfilariae were detected more often in blood samples $(4.5 \%)$ then heartworm antigen using ELISA (1.4\%). One explanation is that microfilariae originated from other filarial species (Dirofilaria repens, Acanthoheilonema reconditum or Dipetalonema dracunculoides) being also endemic 
in Europe and occurring in subcutaneous tissue or peritoneal cavity (Pantchev et al. 2011). Cases of heartworm infections with a negative antigen result but with microfilaria circulating in the blood were also observed, but more rarely (Pantchev et al. 2011). An adulticid treatment, only a few adults, delayed antigenemia or immune complexes are possible reasons for this constellation (Weil et al. 1984, Pantchev et al. 2011). With regard to diagnostic procedures for imported or travel-accompanying dogs within Europe, other filarial species have to be considered in addition to $D$. immitis, but the awareness of veterinarians in Germany to search for microfilariae based on concentration assays (filtration, Knott) was particularly low in the study period 2004-2006 (e.g. only 440 Knott's tests were asked for by veterinarians). Thus, other filarial species than D. immitis were probably underdiagnosed. Currently, many laboratories offer PCR tests for microfilariae in blood samples (also within travel disease profiles), so the risk to miss such infections in dogs appears to be lower. Although the sensitivity of PCRs is generally high, the limit of detection is different and depends on target gene copies, PCR protocol (i.e. single or multiplex reactions), as well as mixed or single filarial infections among others (Pantchev et al. 2011, Cabanova et al. 2015, Ionica et al. 2015, Manzocchi et al. 2017). In the present study, D. immitis was detected only in dogs originating from endemic areas like Spain/ Portugal and Greece. In our findings increased age was a risk factor for dirofilariosis. Elder dogs are usually longer exposed to blood-sucking mosquitoes and therefore also frequently infected with microfilariae (Peres-Sanchez et al. 1989, Poglayen et al. 1996, Miterpakova et al. 2008).

\section{Ehrlichia canis}

In this study a higher seroprevalence was shown compared to DNA detection ( $15.1 \%$ versus $3.2 \%$ ). A persistence of antibodies after disappearance of bacteria from blood can lead to a poor correlation between both methods. Furthermore, in a chronic stage of disease dogs can show a low bacteremia
(Iqbal and Rikihisa 1994, Neer et al. 1999, Breitschwerdt et al. 2002). When comparing different samples using PCR method, a spleen aspirate is more suited sample compared to blood regarding sensitivity (Harrus et al. 1998, Baneth et al. 2009). In the present study female dogs harbored the infection more often than male dogs. The difference in hormone level and inherent immune response could be the reason for the gender susceptibility (Klein 2004). In contrast Sainz et al. (1996), Harrus et al. (1997) and Hernandez et al. (2004) could not find any sex predilection. Harrus et al. (1997) observed a season predilection for ehrlichiosis between May and October. In our study the majority of the dogs had antibodies against Ehrlichia in autumn, presumably associated with the seasonal activity of the vector (Rhipicephalus sanguineus). No information was available about the origin of positively tested dogs, but as most of serology was run within travel-disease-profiles, it can be assumed that these dogs were imported to Germany. Another study found 2 out of 60 seropositive dogs living in Germany to be presumable autochthonous infections, while most of imported infections came from Italy (Kuffer-Frank et al. 1999). One of those two dogs revealed a $R$. sanguineus infestation, presumably introduced from Italy through the partner dog. Krupka et al. (2007) found a seroprevalence of $1.1 \%$ (CI: 0.7-1.5) in randomly sampled German dogs $(n=3,005)$ using a rapid test based on ELISA technology (peptides from p30 and p30 - 1 outer membrane proteins of E. canis; $\left.\mathrm{SNAP}^{\circledR} 4 \mathrm{Dx}^{\circledR}\right)$.

\section{Anaplasma phagocytophilum}

Detection of $A$. phagocytophilum antibodies in $41.9 \%$ of samples was in accordance with results from other studies. E.g. Jensen et al. (2007) found similar seroprevalence in German dogs without history of staying abroad. Krupka et al. (2007) found a seroprevalence of $21.5 \%$ (CI: 20.5-22.6) in German dogs $(n=5,683)$ using a rapid test based on ELISA technology (p44/msp2 antigen; $\mathrm{SNAP}^{\circledR}$ $\left.4 \mathrm{Dx}^{\circledR}\right)$. Overall, a regional seroprevalences of $17.6 \%$ 
to $31.1 \%$ were found in the above mentioned study, with lower seroprevalence in the western part of Germany. In the present study, dogs older than 12 months had more often antibodies against A. phagocytophilum. Age correlation and anaplasmosis in dogs is supported by studies from Sweden and USA (reviewed by Pantchev et al. 2015a). Possible explanation might be that repeated reinfection is necessary (hence older dogs), or a fully developed immune system is required, because Anaplasma impact on various immunological processes in order to survive. In contrast, Jensen et al. (2007) did not reveal any significant difference between age of dogs and anaplasmosis.

\section{Co-infection}

Most of the co-infected dogs in this study had antibodies against $E$. canis and $L$. infantum (Table 4 ). This represents at the same time the most important co-infection from clinical point of view. $E$. canis infection seems to predispose the dogs for Leishmania infection (Mekuzas et al. 2009). Moreover, coinfected dogs develop more frequently clinical signs (Ciaramella et al. 1997, Mekuzas et al. 2009); they show poor platelet aggregation and poor response to treatment as well as more antiplatelet antibodies (Cortese et al. 2009, 2011).

\section{References}

Agut A, Corzo N, Murciano J, Laredo FG, Soler M (2003) Clinical and radiographic study of bone and joint lesions in 26 dogs with leishmaniasis. Vet Rec 153: 648-652

Alonso F, Giménez Font P, Manchón M, Ruiz de Ybáñez R, Segovia M, Berriatua E (2010) Geographical variation and factors associated to seroprevalence of canine leishmaniosis in an endemic Mediterranean area. Zoonoses Public Health 57: $318-328$

Baneth G, Harrus S, Ohnona FS, Schlesinger Y (2009) Longitudinal quantification of Ehrlichia canis in experimental infection with comparison to natural infection. Vet Microbiol 136(3-4): 321-5.

Barutzki D, Reule M, Scheunemann R, Heile C, Schein E (2007) Die Babesiose des Hundes. Eine autochthone Erkrankung in Deutschland. Dt Tierärztebl 55: 284-293

\section{Ethical standards}

All investigations comply with the current laws of the countries in which they were performed.

\section{Competing interests}

The authors declare that they have no competing interests. There is no commercial conflict of interest since the information generated here is solely for scientific dissemination.

\section{Acknowledgment}

We wish to thank Dr. Rose-Marie Binzel and Dr. Claudia Muck for supporting the ocular swab sampling of dogs in Urbach and Schwanstetten.

\section{Open Access}

This article is distributed under the terms of the Creative Commons Attribution 4.0 International License (http://creativecommons.org/licenses/ by/4.0/ ), which permits unrestricted use, distribution, and reproduction in any medium, provided you give appropriate credit to the original author(s) and the source, provide a link to the Creative Commons license, and indicate if changes were made.

Bensoussan E, Nasereddin A, Jonas F, Schnur LF, Jaffe CL (2006) Comparison of PCR assays for diagnosis of cutaneous leishmaniasis. J Clin Microbiol 44: 1435-1439

Beran B (2010) Epidemiology of leishmaniosis in southern germany with emphasis on the family of psychodidae, primarily phlebotominae. Dissertation. Tierärztliche Fakultät der Ludwig-Maximilians-Universität München

Breitschwerdt EB, Abrams-Ogg ACG, Lappin MR, Bienzle D, Hancock SI, Cowan SM, Clooten JK, Hegarty BC, Hawkins EC (2002) Molecular evidence supporting Ehrlichia canislike infection in cats. J Vet Intern Med 16: 642-649

Cabanová V, Pantchev N, Hurníková Z, Miterpáková M (2015) Recent study on canine vector-borne zoonoses in southern Slovakia - serologic survey. Acta Parasitol 60: $749-58$ 
Cardoso L, Rodrigues M, Santos H, Schoone GJ, Carreta P, Vareajo E, van Benthem B, AFonso M.O, Alves-Pires C, Semiao-Santos SJ, Rodrigues J, Schallig HD (2004) Seroepidemiological study of canine Leishmania spp. infection in the municipality of Alijo (Alto Douro, Portugal). Vet Parasitol 121: 21-32

Carret C, Walas F, Carcy B, Grande N, Precigout E, Moubri K, Schetters TP, Gorenflot A (1999) Babesia canis canis, Babesia canis vogeli, Babesia canis rossi: differentiation of the three subspecies by a restriction fragment length polymorphism analysis on amplified small subunit ribosomal RNA genes. J Eukaryot Microbiol 46: 298-303

Carvalho FS, Wenceslau AA, Albuquerque GR, Munhoz AD, Gross E, Carneiro PLS, Oliveira HC, Rocha JM, Santos IA, Rezende RP (2015) Leishmania (Viannia) braziliensis in dogs in Brazil: epidemiology, co-infection, and clinical aspects. Genet Mol Res 14: 12062-12073

Ciaramella, P, Oliva G, de Luna R, Gradoni L, Ambrosio R, Cortese L, Scalone A, Persechino A (1997). A retrospective clinical study of canine leishmaniasis in 150 dogs naturally infected by Leishmania infantum. Vet Rec 22: 539-543

Cortes S, Vaz Y, Neves R, Maia C, Cardoso L, Campino L (2012) Risk factors for canine leishmaniasis in an endemic Mediterranean region. Vet Parasitol 26: 189-196

Cortese L, Pelagalli A, Piantedosi D, Cestaro A, Di Loria A, Lombardi P, Avallone L, Ciaramella P (2009) Effects of therapy on haemostasis in dogs infected with Leishmania infantum, Ehrlichia canis, or both combined. Vet Rec 164(14): 433-434

Cortese L, Terrazzano G, Piantedosi D, Sica M, Prisco M, Ruggiero G, Ciaramella P (2011) Prevalence of anti-platelet antibodies in dogs naturally co-infected by Leishmania infantum and Ehrlichia canis. Vet J 188(1): 118-21

Cringoli G, Rinaldi L, Capuano F, Baldi L, Veneziano V, Capelli G (2002) Serological survey of Neospora caninum and Leishmania infantum co-infection in dogs. Vet Parasitol 106: 307-313

Dixon WJ (1993) BMDP statistical software manual, Volume 1 and 2. University of California Press, Berkeley

Dumitrache MA, Nachum-Biala Y, Gilad M, Mircean V, Cazan CD, Mihalca AD, Baneth G (2016) The quest for canine leishmaniasis in Romania: the presence of an autochthonous focus with subclinical infections in an area where disease occurred. Parasit Vectors 9: 297

Dyachenko V, Pantchev N, Balzer HJ, Meyersen A, Straubinger RK (2012) First case of Anaplasma platys infection in a dog from Croatia. Parasit Vectors 5: 49

Farwell GE, Legrand EK, Cobb CC (1982) Clinical observations on Babesia gibsoni and Babesia canis infections in dogs. J Am Vet Med Assoc 180: 507-511
Gothe R (1991) Leishmaniosen des Hundes in Deutschland: Erregerfauna und -biologie, Epidemolologie, Klinik, Pathogenese, Diagnose, Therapie und Prophylaxe. Kleintierpraxis 36: $69-84$

Gothe R, Nolte I, Kraft W (1997) Leishmaniose des Hundes in Deutschland: epidemiologische Fallanalyse und Alternative zur bisherigen kausalen Therapie. Tierarztl Prax 25: 68-73

Gothe R, Wegerdt S, Walden R, Walden A (1989) Zur Epidemiologie von Babesia canis- und Babesia gibsoni-Infektionen bei Hunden in Deutschland. Kleintierpraxis 34: 309-320

Haeberlein S, Fischer D, Thomas SM, Schleicher U, Beierkuhnlein C, Bogdan C (2013) First Assessment for the Presence of Phlebotomine Vectors in Bavaria, Southern Germany, by Combined Distribution Modeling and Field Surveys. PLoS One 18: 8

Harrus S, Kass PH, Klement E, Waner T (1997) Canine monocytic ehrlichiosis: a retrospective study of 100 cases, and an epidemiological investigation of prognostic indicators for the disease. Vet Rec 141: 360-363

Harrus S, Waner T, Aizenberg I, Foley JE, Poland AM, Bark H (1998) Amplification of Ehrlichial DNA from Dogs 34 Months after infection with Ehrlichia canis. J Clin Microbiol 73-76

Hernandez MB, Perez Diaz JV, Calvet BO, Garcia SV (2004) Serological survey for Ehrlichia canis in dogs from Mediterranean region of Alicante (Spain). Epidemiol et santé anim 45: $81-82$

Hernández L, Montoya A, Checa R, Dado D, Gálvez R, Otranto D, Latrofa MS, Baneth G, Miró, G (2015) Course of experimental infection of canine leishmaniosis: Follow-up and utility of noninvasive diagnostic techniques. Vet Parasitol 207(1-2):149-55

Hirsch M, Pantchev N (2008) Occurrence of travel diseases leishmaniosis, ehrlichiosis, babesiosis and dirofilariosis in dogs living in Germany. Kleintierprax 53: 154-165

Ionică AM, Matei IA, Mircean V, Dumitrache MO, D'Amico G, Győrke A, Pantchev N, Annoscia G, Albrechtová K, Otranto D, Modrý D, Mihalca AD (2015) Current surveys on the prevalence and distribution of Dirofilaria spp. and Acanthocheilonema reconditum infections in dogs in Romania. Parasitol Res 114(3): 975-82

Iqbal Z, Rikihisa Y (1994) Reisolation of Ehrlichia canis from blood and tissues of after doxycycline treatment. J Clin Microbiol 32: 1644-1649

Jensen J, Simon D, Escobar HM, Soller TJ, Bullerdiek J, Beelitz P, Pfister K, Nolte I (2007) Anaplasma phagocytophilum in dogs in Germany. Zoonoses Public Health 54: 94-101 
Karkamo V, Kaistinen A, Näreaho A, Dillard K, VainioSiukola K, Vidgrén G, Tuoresmäki N, Anttila M (2014) The first report of autochthonous non-vector-borne transmission of canine leishmaniosis in the Nordic countries. Acta Vet Scand 56: 84

Keck N, Dereure J (2003) Epidemiology of canine leishmaniasis by cross-sectional study in the French focus of Cevennes. Revue Med Vet 154: 599-604

Klein SL (2004) Hormonal and immunological mechanisms mediating sex differences in parasite infection. Parasite Immunol 26: 247-264

Krupka I, Pantchev N, Weise M, Straubinger RK (2007) [Tick-transmitted, bacterial infections in dogs: Seroprevalences of Anaplasma phagocytophilum, Borrelia burgdorferi sensu lato and Ehrlichia canis in Germany]. Durch Zecken übertragbare bakterielle Infektionen bei Hunden: Seroprävalenzen von Anaplasma phagocytophilum, Borrelia burgdorferi sensu lato und Ehrlichia canis in Deutschland. Praktischer Tierarzt 10(88): 776 - 787, in German

Kuffer-Frank M, Link M, Schipp D, Kraft W (1999) [Canine ehrlichiosis: epidemiology, clinical signs, haematological and biochemical findings in 1996 and 1997 (60 cases). Ehrlichia canis: Epidemiologie, klinische Symptome und labordiagnostische Befunde der Jahre 1996 und 1997 (60 Fälle). Tieräztl Prax 27 (K): 53-58, in German

Le Fichoux Y, Quaranta JF, Aufeuvre JP, Lelievre A, Marty P, Suffia I, Rousseau, D, Kubar J (1999) Occurrence of Leishmania infantum parasitemia in asymptomatic blood donors living in an area of endemicity in southern France. $\mathrm{J}$ Clin Microbiol 37: 1953-1957

Leontides LS, Saridomichelakis MN, Billinis C, Kontos V, Koutinas AF, Galatos AD, Mylonakis ME (2002) A crosssectional study of Leishmania spp. infection in clinically healthy dogs with polymerase chain reaction and serology in Greece. Vet Parasitol 109: 19-27

Maia C, Ramada J, Cristovao JM, Goncalves L, Camoino L (2009) Diagnosis of canine leishmaniasis: conventional and molecular techniques using different tissues. Vet J 179: 142-144

Manna L, Corso R, Galiero G, Cerrone A, Muzj P, Gravino $\mathrm{AE}$ (2015) Long-term follow-up of dogs with leishmaniosis treated with meglumine antimoniate plus allopurinol versus miltefosine plus allopurinol. Parasit Vectors 8: 289

Manzocchi S, Lendner M, Piseddu E, Sebastiani V, Morabito S, Daugschies A, Pantchev N (2017) Nodular presentation of Dirofilaria repens infection in a cat mimicking a fibrosarcoma. Vet Clin Pathol 46(1): 158-163

McBride JW, Corstvet RE, Gaunt SD, Chinsangaram J, Akita GY, Osburn BI (1996) PCR detection of acute Ehrlichia canis infection in dogs. J Vet Diagn Invest 8: 441-447
Melaun C, Krüger A, Werblow A, Klimpel S (2014) New record of the suspected leishmaniasis vector Phlebotomus (Transphlebotomus) mascittii Grassi, 1908 (Diptera: Psychodidae: Phlebotominae) the northernmost phlebotomines and fly occurrence in the Palearctic region. Parasitol Res 113: $2295-2301$

Mekuzas Y, Gradoni L, Oliva G, Foglia Manzillo V, Baneth G (2009) Ehrlichia canis and Leishmania infantum co-infection: a 3-year longitudinal study in naturally exposed dogs. Clin Microbiol Infect 15 (Suppl 2): 30-31

Mettler M, Grimm F, Naucke TJ, Maasjost C, Deplazes P (2005) Canine Leishmaniose in Mitteleuropa: retrospektive Umfrage und serologische Untersuchung importierter und reisebegleitender Hunde. Berl Münch Tierärztl Wschr 118: $37-44$

Miro G, Montoya A, Mateo M, Alonso A, Garcia S, Garcia A, Caballero MJ, Molina R (2007) A leishmaniosis surveillance system among stray dogs in the region of Madrid: ten years of serodiagnosis (1996-2006). Parasitol Res 101: 253-257

Miterpakova M, Antolova D, Hurnikova Z, Dubinsky P (2008) Dirofilariosis in Slovakia - a new endemic area in Central Europe. Helminthologia 45: 20-23

Naucke TJ, Schmitt C (2004) Is leishmaniasis becoming endemic in Germany? Int J Microbiol Suppl 37: 179-181

Neer T, Eddlestone SM, Gaunt SD, Corstvet RE (1999) Efficacy of Enrofloxacin for the treatment of experimentally induced Ehrlichia canis infection. J Vet Intern Med 13: 501-504

Obwaller AG, Poeppl W, Naucke TJ, Luksch U, Mooseder G, Aspöck H, Walochnik J (2014) Stable populations of sand flies (Phlebotominae) in Eastern Austria: a comparison of the trapping seasons 2012 and 2013. Trends Entomol 10: $49-53$

Obwaller AG, Karakus M, Poeppl W, Töz S, Özbel Y, Aspöck H, Walochnik J (2016) Could Phlebotomus mascittii play a role as a natural vector for Leishmania infantum? New data. Parasit Vectors 9: 458

Otranto D, Capelli G, Genchi C (2009a) Changing distribution patterns of canine vector borne diseases in Italy: leishmaniosis vs. Dirofilariosis. Parasit Vectors 2 (Suppl 1): 2

Otranto D, Dantas-Torres F, Breitschwerdt EB (2009b) Managing canine vector-borne diseases of zoonotic concern: part one. Trends Parasitol 25: 157-163

Paltrinieri S, Gradoni L, Roura X, Zatelli A, Zini E (2016) Laboratory tests for diagnosing and monitoring canine leishmaniasis. Vet Clin Pathol 45: 552-578

Pantchev N, Etzold M, Daugschies A, Dyachenko V (2011) Diagnosis of imported canine filarial infections in Germany 2008-2010. Parasitol Res 109 (Suppl 1): 61-76 
Pantchev N, Norden N, Lorentzen L, Rossi M, Rossi U, Brand B, Dyachenko V (2009a) Current survey on the prevalence and distribution of Dirofilaria spp. in dogs in Germany. Parasitol Res 105 (Suppl 1): 63-74

Pantchev N, Schaper R, Limousin S, Norden N, Weise M, Lorentzen L (2009b) Occurrence of Dirofilaria immitis and tick-borne infections caused by Anaplasma phagocytophilum, Borrelia burgdorferi sensu lato and Ehrlichia canis in domestic dogs in France: results of a countrywide serologic survey. Parasitol Res 105 (Suppl 1): 101-114

Pantchev N, Pluta S, Huisinga E, Nather S, Scheufelen M, Vrhovec MG, Schweinitz A, Hampel H, Straubinger RK (2015a) Tick-borne Diseases (Borreliosis, Anaplasmosis, Babesiosis) in German and Austrian Dogs: Status quo and Review of Distribution, Transmission, Clinical Findings, Diagnostics and Prophylaxis. Parasitol Res 114 (Suppl 1): 19-54

Pantchev N, Schnyder M, Globokar Vrhovec M, Schaper R, Tsachev I (2015b) Current surveys of the seroprevalence of Borrelia burgdorferi, Ehrlichia canis, Anaplasma phagocytophilum, Leishmania infantum, Babesia canis, Angiostrongylus vasorum and Dirofilaria immitis in dogs in Bulgaria. Parasitol Res 114 (Suppl 1): 117-130

Peres-Sanchez R, Gomez-Bautista M, Encinas Grandes A (1989) Canine filariasis in Salamanca (northwest Spain). Ann Trop Med Parasitol 83: 143-150

Poglayen G, Martini M, Bomben L, Roda R (1996) An updating of the occurrence of canine heartworm disease in northern Italy. Vet Res Commun 20: 303-307

Porchet MJ, Sager H, Muggli L, Oppliger A, Müller N, Frey C, Gottstein B (2007) Etude epidemiologique descriptive de la Babesiose canine dans la Region Lemanique. Schweiz Arch Tierheilkd 149: 459-462

Sainz A, Tesouro MA, Rodriguez F, Mayoral I, Mazzucchelli F (1995) Seroprevalence of Ehrlichia canis infections in police dogs in Spain. Prev Vet Med 23: 179-182

Saridomichelakis MN (2009) Advances in the pathogenesis of canine leishmaniasis: epidemiologic, and diagnostic implications. Vet Dermatol 20: 471-489

Solano-Gallego L, Llull J, Osso M, Hegarty B, Breitschwerdt E (2006) A serological study of exposure to arthropodborne pathogens in dogs from northeastern Spain. Vet Res 37: 231-244

Solano-Gallego, L, Villanueva-Saz S, Carbonell M, Trotta M, Furlanello T, Natale A (2014) Serological diagnosis of canine leishmaniosis: comparison of three commercial ELISA tests (Leiscan, ID Screen and Leishmania 96), a rapid test (Speed Leish K) and an in-house IFAT. Parasit Vectors 7: 111
Soubasia N, Theodorou K, Kasabalis D (2013) Prevalence of arthritis in naturally infected leishmanial dogs: a prospective study. In: Proceedings of the BSAVA Congress, Birmingham, England, p. 586

Steuber S, Moritz A, Schirrmann I, Greiner M (1998) PCR follow-up examination after treatment of canine leishmaniasis (CaL). Tokai J Exp Clin Med 23: 285-292

Strauss-Ayali D, Jaffe CL, Burshtain O, Gonen L, Baneth G (2004) Polymerase chain reaction using noninvasively obtained samples, for the detection of Leishmania infantum DNA in dogs. J Infect Dis 189: 1729-1733

Teske E, van Knapen F, Beijer EGM, Slappendel RJ (2002) Risk of infection with Leishmania spp. in the canine population in the Netherlands. Acta Vet Scand 43: 195-201

Van Eys GJ, Schoone GJ, Kroon NC, Ebeling SB (1992) Sequence analysis of small subunit ribosomal RNA genes and its use for detection and identification of Leishmania parasites. Mol Biochem Parasitol 51: 133-142

Weil GJ, Malane MS, Powers KG (1984) Detection of circulating parasite antigens in canine dirofilariasis by counterimmunoelectrophoresis. Am J Trop Med Hyg 33(3): 425-30

Willi B, Spiri AM, Meli ML, Grimm F, Beatrice L, Riond B, Bley T, Jordi R, Dennler M, Hofmann-Lehmann R (2015) Clinical and molecular investigation of a canine distemper outbreak and vector-borne infections in a group of rescue dogs imported from Hungary to Switzerland. Vet Res 11: 154

Wolf D, Failing K, Taubert A, Pantchev N (2014) Serological diagnosis of canine leishmaniosis: comparison of three commercially available tests. Parasitol Res 113: 1997-2002

Zaffaroni E, Rubaudo L, Lanfranchi P, Mignone W (1999) Epidemiological patterns of canine leishmaniosis in Western Liguria (Italy). Vet Parasitol 81: 11-19

Zahler M, Loster F, Merkle C, Rinder H, Gothe R (2000) Infektionsgefahr für Hunde in Regensburg-ein neuer Naturherd von Babesia canis und Dermacentor reticulatus in Deutschland. Tierärztl Prax 28: 395-398

Zivicnjak T, Martinkovic F, Marinculic A, Mrljak V, Kucer N, Matijatko V, Mihaljevic Z, Baric-Rafaj R (2005) A seroepidemiologic survey of canine visceral leishmaniosis among apparently healthy dogs in Croatia. Vet Parasitol 131: 35-43

Zygner W, Gorski, P, Wedrychowicz H (2009) Detection of the DNA of Borrelia afzelii, Anaplasma phagocytophilum and Babesia canis in blood samples from dogs in Warsaw. Vet Rec 164: 465-467 